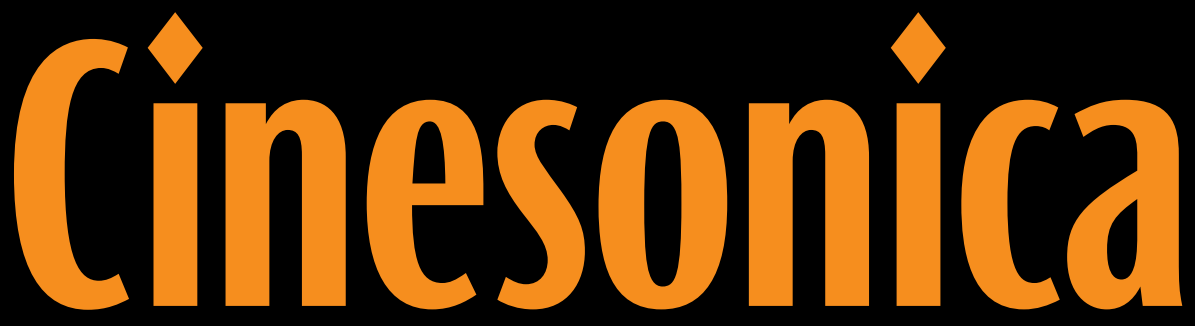

Sounding film and video
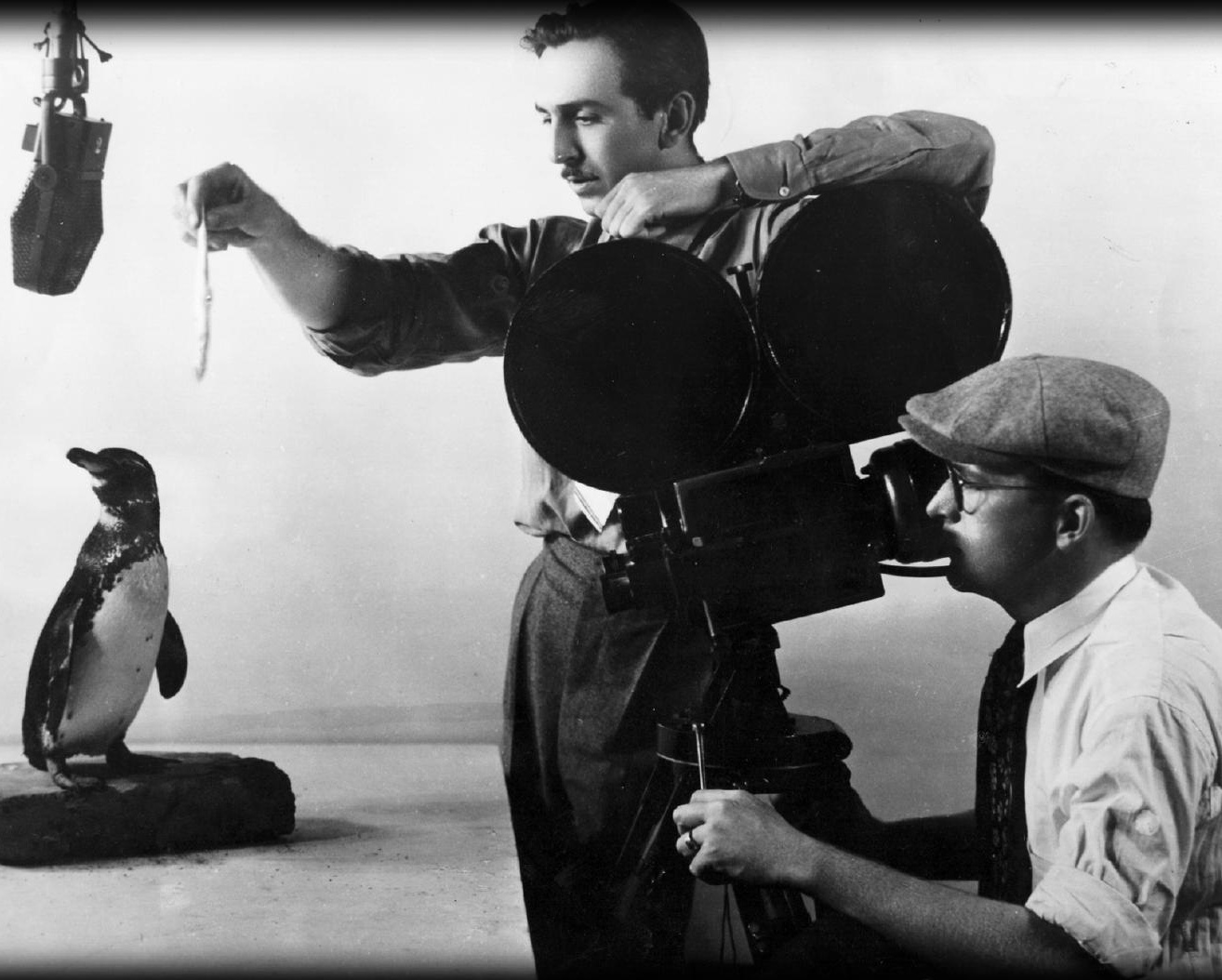

\title{
Andy Birtwistle
}


Cinesonica: sounding film and video

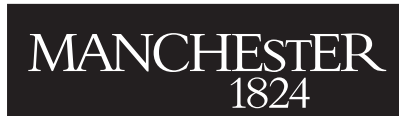

Manchester University Press 
Andy Birtwistle - 9781526129697

Downloaded from manchesterhive.com at $04 / 26 / 2023$ 10:17:48AM 


\title{
Cinesonica: sounding film and video
}

\author{
ANDY BIRTWISTLE
}

\author{
Manchester \\ University Press
}

Manchester 
Copyright (C) Andy Birtwistle 2010

The right of Andy Birtwistle to be identified as the author of this work has been asserted by him in accordance with the Copyright, Designs and Patents Act 1988.

Published by Manchester University Press

Altrincham Street, Manchester MI 7JA, UK

www.manchesteruniversitypress.co.uk

British Library Cataloguing-in-Publication Data

A catalogue record for this book is available from the British Library

Library of Congress Cataloging-in-Publication Data applied for

ISBN 9780719081118 hardback

First published 2010

The publisher has no responsibility for the persistence or accuracy of URLs for any external or third-party internet websites referred to in this book, and does not guarantee that any content on such websites is, or will remain, accurate or appropriate.

Typeset in Charter ITC

by Servis Filmsetting Ltd, Stockport, Cheshire 